\title{
Mycelial growth and microscopic characteristics of Thermomyces lanuginosus Tsiklinskaya in YpSs medium with different carbon sources
}

\author{
Giancarlo Soncini Júnior ${ }^{1,3}$, Sandra Mara Martins Franchetti ${ }^{1}$, Rosely Ana Piccolo Grandi ${ }^{2}$ and \\ José Carlos Marconato ${ }^{1}$
}

Received: 23.11.2006; accepted: 31.05.2007

\begin{abstract}
Mycelial growth and microscopic characteristics of Thermomyces lanuginosus Tsiklinskaya in YpSs medium with different carbon sources). Most thermophilic moulds are known to be lipase producers and the potential for esterification by reversal of lipase hydrolysis has long been recognized. We evaluated the mycelial aspects of T. lanuginosus growing in Petri dishes in YpSs (yeast extract + starch + agar) medium control and four other media based on YpSs containing different carbon source. These raw materials evaluated as carbon sources suppliers for microorganism were pentaerythritol, oleic acid and pentaerythritol dioleate are commonly used in several classic industrial esters synthesis. Thermomyces lanuginosus growed in all studied media and kept its reproduction capacity, showing that this fungus is a promising alternative for future studies of live microorganism's biocatalysts.
\end{abstract}

Key words: carbon source, culture media, thermophilic fungus

RESUMO - (Crescimento micelial e características microscópicas de Thermomyces lanuginosus Tsiklinskaya em meio de cultura YpSs com diferentes fontes de carbono). Muitos fungos termofílicos são conhecidos como sendo produtores de lipases e o potencial dessas enzimas nas reações de esterificação (reação inversa à hidrólise), há muito tem sido reconhecida. $\mathrm{O}$ aspecto do micélio e diversas observações microscópicas foram efetuadas em Thermomyces lanuginosus cultivado em Placas de Petri com meios de culturas YpSs (extrato de levedura + amido + agar) e mais quatro variações na fonte de carbono neste meio. As matérias-primas usadas e avaliadas foram pentaeritritol, ácido oléico e dioleato de pentaeritritol como possíveis fontes de carbono disponíveis ao microrganismo são comumente encontradas na indústria química como intermediários clássicos na síntese de diversos ésteres. Com o crescimento de Thermomyces lanuginosus em todos os meios propostos e a manutenção da capacidade de reprodução mostramos ser esse fungo altamente promissor em futuros trabalhos de biocatálise com microrganismos vivos.

Palavras-chave: fonte de carbono, fungo termofílico, meio de cultura

\section{Introduction}

Thermophilic fungi are microorganisms that have a minimum temperature of growth at or above $20^{\circ} \mathrm{C}$ and a maximum temperature of growth extending up to $60-62^{\circ} \mathrm{C}$ (Maheshwari et al. 2000). Although nearly all of the thermophilic fungi appeared abundantly on natural substrata, it was not always easy to get them established on laboratory media. Several reports postulated that nearly half of the species of thermophilic fungi required yeast extract for growth in a solid medium (Cooney \& Emerson 1964, Fergus 1969a, b). Thus, for growth in a solid medium the thermophilic fungi required water, aeration and nutritional factors like carbon and vitamins sources (Cooney \& Emerson 1964, Maheshwari et al. 2000).

The yeast-starch agar medium (YpSs) was particularly favorable to thermophilic fungi and it is based on salts, soluble starch and yeast extract (Cooney $\&$ Emerson 1964). The carbon source could be changed by others raw materials, even those commonly used in several chemical ester synthesis.

As enzymatic synthesis would be attractive as compared to chemically catalyzed routes in terms of energy and processing costs, several approaches has been developed by esterification using hydrolases (lipases) as a catalysts (Roberts et al. 1995). It is generally accepted that an enzymatic reaction is

1. Universidade Estadual Paulista, Departamento de Bioquímica e Microbiologia, Caixa Postal 199, 13506-900 Rio Claro, SP, Brazil

2. Instituto de Botânica, Caixa Postal 3005, 01061-970 São Paulo, SP, Brazil

3. Corresponding author: simcachambord@ig.com.br 
virtually reversible and, hence, the equilibrium can be controlled by appropriately selecting the reaction conditions (Roberts et al. 1995). As biotechnology is increasingly incorporated into many industrial processes, there is a need to explore biotechnological approaches to the manufacture of new products showing industrial interest. Thermomyces lanuginosus lipase (Lipolase; Novo Industri A/S) is already being used in detergent formulation in conjunction with other microbial enzymes (e.g., protease, amylase, and cellulase). In addition, T. lanuginosus lipases have applications in the food industry and are used for the biocatalysis of stereoselective transformations (Jaeger \& Reetz 1998).

In view of the intensive investigations that have been made of thermophilic algae and bacteria, the lack of knowledge about thermophilic fungi is quite surprising, also in terms of their morphology, specially when they are exposed to industrial raw materials (Maheshwari et al. 2000). Alexopoulos et al. (1996) stated that a character is any attribute or feature of an organism that can serve as a basis for comparison with other organisms. The different expressions of a character are known as character states. Thus, these characters, mainly reproductive structures like conidiophores and conidia to anamorphic group, were useful to known if they were keeping when microorganisms growth on uncommon substrate.

The aims of this work were to evaluate the growth and the morphological characters in Thermomyces lanuginosus exposed to raw materials used in ester synthesis like pentaerythritol, oleic acid and the ester formed by the esterification between pentaerythritol and oleic acid, as the only carbon source available in the media.

\section{Material and methods}

Thermomyces lanuginosus IOC 4145 used in this study was originated from culture at UNESP/ IBILCE - São José do Rio Preto, São Paulo. Colonies were obtained from stock cultures maintained on YpSs at $50{ }^{\circ} \mathrm{C}$ with periodic replication. The fungus was grown on five different kinds of yeast extract + starch + agar media, being the first one, the YpSs standard composition (Emerson 1941). The others versions, v. I, v. II, v. III, and v. IV (the last one without carbon source) were alternative media containing each one, a different carbon source (table 1). The following media components were tested:

Pentaerythritol (v. I) - Produced by Copenor. It is a polyol used in the fabrication of several esters and polyesters. It can be prepared by condensation of acetaldehyde and formaldehyde in a basic environment. The process occurs by successive aldol condensations followed a Cannizaro reaction (Carey \& Sundberg 1990).

$\mathrm{CH}_{3} \mathrm{CHO}+4 \mathrm{CH}_{2} \mathrm{O}+1 / 2 \mathrm{Ca}(\mathrm{OH})_{2} \rightarrow \mathrm{C}\left(\mathrm{CH}_{2} \mathrm{OH}\right)_{4}+$ $1 / 2(\mathrm{HCOO})_{2} \mathrm{Ca}$

Oleic Acid (v. II) - Produced by Braido. It is a monounsaturated fatty acid found in various animal and vegetable sources. It has the following empirical formula: $\mathrm{C}_{18} \mathrm{H}_{34} \mathrm{O}_{2}$. Its IUPAC name is cis-9octadecenoic acid, the lipid shorthand name is $18: 1$ cis-9. It is produced by the hydrolysis of bovine tallow and found several applications in esters synthesis (Carey \& Sundberg 1990).

Pentaerythritol dioleate (v. III) - The last one was obtained in the laboratory by the acylation of pentaerythritol $(1 \mathrm{~mol})$ by reaction with oleic acid ( 2 mols). To drive the reaction forward, the glycol is

Table 1. The standard YpSs medium composition (yeast-starch agar) and its four variations based on carbon source substitution.

\begin{tabular}{|c|c|c|c|c|c|c|c|c|c|c|c|}
\hline \multirow[b]{2}{*}{ Media } & \multicolumn{11}{|c|}{ Raw materials } \\
\hline & $\begin{array}{l}\text { Powdered } \\
\text { yeast } \\
\text { extract }(g)\end{array}$ & $\begin{array}{c}\mathrm{MgSO}_{4} \cdot 7 \mathrm{H}_{2} \mathrm{O} \\
(\mathrm{g})\end{array}$ & $\begin{array}{l}\mathrm{K}_{2} \mathrm{HPO}_{4} \\
\quad(\mathrm{~g})\end{array}$ & $\begin{array}{l}\text { Solubre } \\
\text { starch } \\
\text { (g) }\end{array}$ & $\begin{array}{l}\text { Pentaerythritol } \\
\text { (g) }\end{array}$ & $\begin{array}{l}\text { Oleic } \\
\text { acid } \\
(\mathrm{g})\end{array}$ & $\begin{array}{c}\text { Pentaerythritol } \\
\text { dioleate } \\
\text { (g) }\end{array}$ & $\begin{array}{l}\text { Triton } \\
\mathrm{X}-100 \\
\text { (g) }\end{array}$ & $\begin{array}{c}\text { Tween } \\
40 \\
(\mathrm{~g})\end{array}$ & $\begin{array}{l}\text { Agar } \\
\text { (g) }\end{array}$ & $\begin{array}{c}\text { Distilled } \\
\text { water } \\
\text { (ml) }\end{array}$ \\
\hline $\begin{array}{c}\text { YpSs(Emerson } \\
1941)\end{array}$ & 4.0 & 0.5 & 1.0 & 15.0 & - & - & - & - & - & 20.0 & 1000 \\
\hline YpSs (v. I) & 4.0 & 0.5 & 1.0 & - & 15.0 & - & - & - & - & 20.0 & 1000 \\
\hline YpSs (v. II) & 4.0 & 0.5 & 1.0 & - & - & 15.0 & - & 1.0 & 1.0 & 20.0 & 1000 \\
\hline YpSs (v. III) & 4.0 & 0.5 & 1.0 & - & - & - & 15.0 & 1.0 & 1.0 & 20.0 & 1000 \\
\hline YpSs (v. IV) & 4.0 & 0.5 & 1.0 & - & - & - & - & - & - & 20.0 & 1000 \\
\hline
\end{tabular}


used in large $\mathrm{OH}$ equivalent excess, and it is also necessary to remove water as it is formed (Carey \& Sundberg 1990). As like as oleic acid pentaerythritol dioleate shows no solubility in water, to elaborate YpSs media with these carbon sources an emulsion must be consider. It is seen to consist of a liquid medium in which are suspended minute droplets of a second liquid. The medium is water and the droplets are oil ("oil-in-water"). The addition of 2 drops of Triton X-100 ( $\alpha$-[4-(1,1,3,3-tetramethylbutyl)phenyl]-whydroxypoly(oxy-1,2-ethanediyl) and Tween 40 (polysorbate) in $50 \mathrm{ml}$ of YpSs v. II and YpSs v. III, created stables emulsions like water/oleic acid and water/pentaerythritol dioleate.

Inoculum and growing conditions - the fungus was inoculated for six days in YpSs standard, and several dishes (10 mm diameter) were token and re-introduced each one in a new Petri dish containing YpSs, YpSs v. I, YpSs v. II, YpSs v. III and YpSs v. IV. The cultures were inoculated at $50{ }^{\circ} \mathrm{C}$ in Petri dishes for six days.

To evaluate any possible variation regarding hyphae, conidiophores, and conidia morphology in the cultures of Thermomyces lanuginosus, the fungus was compared in all media tested by taxonomic literature (Cooney \& Emerson 1964, Pugh et al. 1964, Awao \& Mitsugi 1973, Nicoli \& Russo 1974, Domsch et al. 1993). A triplicate criteria was adopted for each medium. All slides were staining with lactophenol cotton blue, a dye utilized for fungi to observe somatic and reproductive structures (Kirk et al. 2001).

The $\mathrm{pH}$ values and its effect on growth at $50{ }^{\circ} \mathrm{C}$ were determinated directly on these five media. Every day during six days, measurement of colony diameter in Petri dishes was the method chosen here to assess growth and the $\mathrm{pH}$ was measured by a $\mathrm{pHmeter}$ Digimed, model DMPH-1, after the dilution of each used medium with deionizated water $1: 1 \mathrm{w} / \mathrm{w}$.

\section{Results and Discussion}

The mycelial growth (diameter increase) of Thermomyces lanuginosus was daily monitored during six days at $50^{\circ} \mathrm{C}$ and the summary data in table 2 show several aspects of the microscopic characteristics of the culture. This fungus can grows in all tested media maintaining the characteristics of the species (Cooney \& Emerson 1964, Pugh et al. 1964, Awao \& Mitsugi 1973, Nicoli \& Russo 1974, Domsch et al. 1993).

When an emulsion is examined under a microscope, we observed few conidia and detached from conidiophores in both cases (v. II and v. III) when compared with YpSs standard and YpSs v. I (table 2). When no theoretical carbon source is added to the medium (YpSs v. IV where yeast extract is consider as a vitamin source), the sporulation is very intense and growth is very similar compared to the standard medium YpSs.

Depending on the hydrophobic character of the evaluated carbon source, to prepare a stable mixture in water of such "insoluble" raw material, making it available to the microorganisms, it is necessary to incorporate a surface active agent called an "emulsifier", which keeps one liquid more or less permanently dispersed in the other. This condition is called emulsion by the action of an emulsifying agent (Roberts et al. 1995). There were few conidia in both cases compared with YpSs standard and YpSs v. I.

Although Thermomyces lanuginosus is capable of sporulate in all YpSs media evaluated, some macroscopical differences were observed in Petri dishes. The colonies appear white and felty at first, and also very thin. But soon, (regarding Thermomyces lanuginosus inoculated in $\mathrm{YpSs}$ ), they turn grey or greenish grey, beginning at the center of the colony. It is also possible to see the presence of some exudation drops. Gradually the colony turns purplish brown, and at this time the agar substratum stains a deep pink or wine color, due to diffusible substances secreted by the colony. With different carbon sources, even with less growth, the presence of a wine color was noted only in YpSs v. II (oleic acid as carbon source).

The data in table 3 show a considerable growth of Thermomyces lanuginosus in YpSs v. IV, a medium without a specific carbon source. The necessity of this fungus regarding the presence of yeast extract was clearly noted such as reported by Cooney \& Emerson (1964), Fergus (1969a, b). All media tested without addition of this component showed no growth. The conidia obtained from YpSs, YpSs v. I, YpSs v. II, YpSs v. III and YpSs v. IV, were replicated in the same media, showing always the same mycelial growing.

Based on a triplicate, $\mathrm{pH}$ values are shown in table 4. Considerable changes in $\mathrm{pH}$ were observed in YpSs v. II. Based on an estimated log octanol/water partition coefficient of 7.73 and a regression derived equation, the Koc for undissociated oleic acid can be estimated to be approximately 38,000 . This Koc value indicates that oleic acid will be immobile in soil. Due 
Table 2. The microscopic characteristics of Thermomyces lanuginosus in standard YpSs medium and its four variations based on carbon source substitution.

\begin{tabular}{|c|c|c|c|c|c|}
\hline \multirow[b]{2}{*}{ Media } & \multicolumn{5}{|c|}{ Macroscopic characteristics } \\
\hline & Hyphae & Conidiophores & Conidia & $\begin{array}{l}\text { Conidia diameter } \\
\qquad(\mu \mathrm{m})\end{array}$ & Separated conidia \\
\hline YpSs (Emerson 1941) & $\begin{array}{l}\text { Septate, } \\
\text { branched }\end{array}$ & $\begin{array}{l}\text { Short, unbranched } \\
\text { or rarely } \\
\text { branched }\end{array}$ & $\begin{array}{c}\text { Single on each } \\
\text { conidiophore, spherical, } \\
\text { hyaline and smooth-walled } \\
\text { when young }\end{array}$ & 5 to 7 & None \\
\hline YpSs (v. I) & $\begin{array}{l}\text { Septate, } \\
\text { branched }\end{array}$ & $\begin{array}{l}\text { Short, unbranched } \\
\text { or rarely } \\
\text { branched }\end{array}$ & $\begin{array}{c}\text { Single on each } \\
\text { conidiophore, spherical, } \\
\text { hyaline and smooth-walled } \\
\text { when young }\end{array}$ & 5 to 7 & None \\
\hline YpSs (v. II) & $\begin{array}{l}\text { Septate, } \\
\text { branched }\end{array}$ & $\begin{array}{l}\text { Short, unbranched } \\
\text { or rarely } \\
\text { branched }\end{array}$ & $\begin{array}{c}\text { Single on each } \\
\text { conidiophore, spherical, } \\
\text { hyaline and smooth-walled } \\
\text { when young }\end{array}$ & 5 to 7 & Present \\
\hline YpSs (v. III) & $\begin{array}{l}\text { Septate, } \\
\text { branched }\end{array}$ & $\begin{array}{l}\text { Short, unbranched } \\
\text { or rarely } \\
\text { branched }\end{array}$ & $\begin{array}{c}\text { Single on each } \\
\text { conidiophore, spherical, } \\
\text { hyaline and smooth-walled } \\
\text { when young }\end{array}$ & 5 to 7 & Present \\
\hline YpSs (v. IV) & $\begin{array}{l}\text { Septate, } \\
\text { branched }\end{array}$ & $\begin{array}{c}\text { Short, unbranched } \\
\text { or rarely } \\
\text { branched }\end{array}$ & $\begin{array}{c}\text { Single on each } \\
\text { conidiophore, spherical, } \\
\text { hyaline and smooth-walled } \\
\text { when young }\end{array}$ & 5 to 7 & None \\
\hline
\end{tabular}

to the $p K a$ value of 5.02 , oleic acid will be $99 \%$ dissociated at $\mathrm{pH} 7$ but it was very interesting to observe the fungus ability to adjust the hydrogen-ion concentration. Most fungi grow best at approximately $\mathrm{pH} 7$ but tolerate a wide range from 3-10 (Kirk et al. 2001). An initial $\mathrm{pH}$ of 6.5 to 7 has been used for most organisms, although in most cases the final $\mathrm{pH}$ shifts towards alkaline range (Liu et al. 1973). This effect was confirmed for Thermomyces lanuginosus too. Several studies have dealt with the physiological and environmental factors affecting synthesis and production of extracellular proteases by thermophilic fungi. Although there are distinct differences between organisms, synthesis of many proteases is governed, at least in part, by the type and concentration of the available individual nutrients (Somukuti \& Babel 1968). The production of extracellular protease by thermophilic Achaetomium macrosporum J.N. Rai et al., Chaetomium thermophilum La Touche, Thermomyces lanuginosus, Sporotrichum thermophile Apinis and Torula thermophila Cooney $\&$ R. Emers. was enhanced by the addition of casein, gelatin, glucose and maltose (Somukuti \& Babel 1968). The proteases produced by Thermomyces lanuginosus are considering as alkaline protease type (Satayanarayana \& Johri 1983).

Table 3. Measurement of mycelial growth media (diameter) of Thermomyces lanuginosus inoculated in standard YpSs (yeast extract + starch + agar) medium, and its four variations based on carbon source substitution. Diameters (mm) were based on a triplicate.

\begin{tabular}{|c|c|c|c|c|c|c|}
\hline \multirow[b]{2}{*}{ Media } & \multicolumn{6}{|c|}{ Period of obsevation } \\
\hline & $\begin{array}{l}1^{\text {st }} \text { day } \\
(\mathrm{mm})\end{array}$ & $\begin{array}{l}2^{\text {nd }} \text { day } \\
(\mathrm{mm})\end{array}$ & $\begin{array}{c}3^{\text {rd }} \text { day } \\
(\mathrm{mm})\end{array}$ & $\begin{array}{l}4^{\text {th }} \text { day } \\
(\mathrm{mm})\end{array}$ & $\begin{array}{l}5^{\text {th }} \text { day } \\
(\mathrm{mm})\end{array}$ & $\begin{array}{c}6^{\text {th }} \text { day } \\
(\mathrm{mm})\end{array}$ \\
\hline YpSs (Emerson 1941) & 5 & 11.5 & 24.5 & 35 & $>35$ & $>35$ \\
\hline YpSs (v. I) & 5 & 10 & 19.5 & 23.5 & 29.5 & 35 \\
\hline YpSs (v. II) & 1.5 & 4 & 6.5 & 8 & 12 & 16.5 \\
\hline YpSs (v. III) & 2 & 6 & 15.5 & 21 & 27 & 30 \\
\hline YpSs (v. IV) & 4 & 9 & 19 & 22 & 28.5 & 35 \\
\hline
\end{tabular}


Table 4. Measurement of $\mathrm{pH}$ media of Thermomyces lanuginosus inoculated in standard YpSs medium and its four variations based on carbon source substitution. Data based on a triplicate.

\begin{tabular}{lccc}
\hline & \multicolumn{3}{c}{ pH measurements } \\
\cline { 2 - 4 } & $\begin{array}{c}\text { Initial } \mathrm{pH} \\
50^{\circ} \mathrm{C}\end{array}$ & $\begin{array}{c}\text { Initial } \mathrm{pH} \\
50^{\circ} \mathrm{C} \\
\text { diluted } 1: 1(\mathrm{w} / \mathrm{w})\end{array}$ & $\begin{array}{c}\text { Final } \mathrm{pH} \\
50^{\circ} \mathrm{C} \\
\text { Media }\end{array}$ \\
\hline YpSs (Emerson 1941) & 7.16 & 7.31 & 7.87 \\
YpSs (v. I) & 7.27 & 7.34 & 7.85 \\
YpSs (v. II) & 6.11 & 6.21 & 7.04 \\
YpSs (v. III) & 7.17 & 7.28 & 7.47 \\
YpSs (v. IV) & 7.21 & 7.33 & 7.71 \\
\hline
\end{tabular}

Therefore, Thermomyces lanuginosus survived and showed a considerable growth in all media tested, specially in YpSs v. III that contains an ester and also a residual oleic acid. Some macroscopical differences were noted regarding the cultures morphology, but no significant differences were observed in a microscopical study, showing stability in the conidiogenesis. However, the capacity of this fungus to grow when the YpSs medium had its carbon source substituted by glycols, fatty acids and esters synthesized in glass kettles was confirmed.

In order to evaluate an eventual improvement of lipase production, or even the capacity of Thermomyces lanuginosus to grow with different carbon sources, additional studies of the effects of sterols, vitamins, and other nutrients on the mycelial growth and sporulation of this fungus would be useful to confirm thermophilic microorganism as a promising alternative for immobilized biocatalysts.

\section{Literatured cited}

Alexopoulos, C.J., Mims, C.W. \& Blackwell, M. 1996. Introductory Mycology. $4^{\text {th }}$ ed. John Wiley \& Sons, New York.

Awao, T. \& Mitsugi, K. 1973. Notes on thermophilic fungi in Japan (1). Transactions of the Mycological Society of Japan 14: 145-160.

Carey, F.A \& Sundberg, R.J. 1990. Advanced Organic Chemistry. Part A: Structure and Mechanisms. $3^{\text {rd }}$ ed. Plenum Press, New York.

Cooney, D.G. \& Emerson, R. 1964. Thermophilic Fungi. $1^{\text {st }}$ ed. W. H. Freeman and Company, San Francisco.

Domsch, K.H., Gams, W. \& Anderson, T.-H. 1993. Compendium of Soil Fungi. $1^{\text {st }}$ ed. IHW-Verlag, Eching.
Emerson, R. 1941. An experimental study of the life cycles and taxonomy of Allomyces. Lloydia 4: 77-144.

Fergus, C.L. 1969a. The cellulolytic activity of thermophilic fungi and actinomycetes. Mycologia 61: 120-129.

Fergus, C.L. 1969b. The production of amylase by some thermophilic fungi. Mycologia 61: 1171-1175.

Jaeger, K.-E \& Reetz, M.T. 1998. Microbial lipases from versatile tools for biotechnology. Trends in Biotechnology 16: 396-403.

Kirk, P.M., Cannon, P.F., David, J.C. \& Stalpers, J.A. 2001. Dictionary of the Fungi. $9^{\text {th }}$ ed. CAB Institutional, Wallingford.

Liu, W.H., Beppu, T. \& Arima, K. 1973. Purification and properties of the lipase of thermophilic fungus Humicola lanuginosa S-38. Agricultural \& Biological Chemistry 37: 157-163.

Maheshwari, R., Bharadwaj, G. \& Bhat, M.K. 2000. Thermophilic Fungi: their physiology and enzymes. Microbiology and Molecular Biology Reviews 64: 461-488.

Nicoli, R.M. \& Russo, A. 1974. Le genre Humicola Traaen et les genres voisins (Hyphomycetes). Nova Hedwigia 25: 737-798.

Pugh, G.J.F., Blakeman, J.P. \& Morgan-Jones, G. 1964. Thermomyces verrucosus sp. nov. and T. lanuginosus. Transactions of the British Mycological Society 47: 115-121.

Roberts, S.M., Turner, N.J., Willetts, A.J. \& Turner, M.K. 1995. Introduction to biocatalysis using enzymes and micro-organisms. $1^{\text {st }}$ ed. Cambridge University Press, New York.

Satayanarayana, T. \& Johri, B.N. 1983. Extracellular proteases of thermophilic fungi isolated from decomposing paddy straw. Tropical Plant Science 1: 137-140.

Somukuti, G.A. \& Babel, F.J. 1968. Conditions influencing the synthesis of acid protease by Mucor pusillus Lindt. Applied Microbiology 15: 1309-1312. 